\title{
EDUKASI PEMBERIAN MAKANAN TAMBAHAN BAGI IBU BALITA GIZI KURANG
}

\author{
Susana Limanto \\ Prodi Teknik Informatika, Fakultas Teknik, Universitas Surabaya, susana@staff.ubaya.ac.id \\ Liliana \\ Prodi Teknik Informatika, Fakultas Teknik, Universitas Surabaya
}

\section{Surono Purba}

Prodi Teknik Informatika, Fakultas Teknik, Universitas Surabaya

\begin{abstract}
Abstrak
Anak adalah calon generasi penerus bangsa yang perlu disiapkan sejak dini sehingga mampu menjadi Sumber Daya Manusia (SDM) penerus bangsa yang berkualitas. Proses untuk menyiapkan SDM yang berkualitas seharusnya sudah dimulai sejak perencanaan pernikahan, masa kehamilan, kelahiran, anak, dewasa, hingga lansia. Masa yang paling kritis adalah masa kehamilan dan kelahiran sampai dengan usia 1000 hari pertama kelahiran. Untuk itu, pada usia tersebut diperlukan zat gizi yang bermutu dan memadai. Pemerintah bertanggungjawab untuk menyediakan sarana dan prasarana kesehatan sehingga masyarakat dapat memperoleh layanan kesehatan yang layak secara merata. Pelayanan yang diberikan oleh puskesmas Sawahan terutama diperuntukkan bagi masyarakat di kelurahan Sawahan dan Petemon. Berdasarkan data direktorat gizi masyarakat tahun 2018 menunjukkan bahwa jumlah balita gizi kurang di kelurahan Sawahan dan Petemon masih cukup banyak. Apabila balita gizi kurang yang ada di kelurahan Sawahan dan Petemon tidak segera ditangani dengan baik, maka balita tersebut berpotensi berubah status menjadi gizi buruk. Potensi permasalahan mitra di wilayah kerja puskesmas Sawahan adalah gizi kurang pasca kejadian balita gizi buruk dapat berpotensi menjadi kondisi stunting. Oleh karena itu, tim Abdimas dari Universitas Surabaya berinisiatif untuk membantu puskesmas Sawahan melalui kegiatan pemberian makanan tambahan yang dilakukan beberapa tahapan seperti sosialisasi, demo masak, monitoring dan evaluasi, dengan tujuan untuk memberikan edukasi pada ibu yang memiliki batita, agar dapat memberikan makanan yang sesuai dengan usianya. Hasil awal kuisioner adalah $83 \%$ peserta posyandu mengetahui tumbuh kembang anak dan lebih dari $50 \%$ Ibu peserta posyandu hanya sebulan sekali komunikasi dengan tenaga kesehatan.
\end{abstract}

Kata Kunci: batita gizi kurang, pos pelayanan terpadu (posyandu), edukasi

\section{Abstract}

Children are prospective candidates for the next generation that need to be prepared early so they are able to become qualified human resources $(H R)$. The process of preparing quality human resources should have been started since planning the wedding, the period of pregnancy, birth, child, adult, until the elderly. The most critical period is the period of pregnancy and birth until the age of the first 1000 days of birth. For this reason, at that age, quality and adequate nutrients are needed. The government is responsible for providing health facilities and infrastructure so that the community can obtain equitable health services equally. The services provided by the Sawahan Community Health Center are mainly for the people in Sawahan and Petemon villages. Based on data from the directorate of community nutrition in 2018 shows that there are still a large number of malnourished children under five in Sawahan and Petemon villages. If underweight children under five in Sawahan and Petemon Subdistricts are not immediately handled properly, the toddler has the potential to change status to malnutrition. Potential partner problems in the Sawahan Health Center work area are Nutritionally Poor after the occurrence of Malnutrition Toddler can potentially become a stunting condition. Therefore, the Abdimas team from the University of Surabaya took the initiative to help Sawahan Health Center through this service program, providing supplementary food who carried out several stages such as socialization, cooking and demonstrations, monitoring and evaluation. with the aim of providing education to mothers who have toddlers, in order to be able to provide food according to their age. The initial results of the questionnaire is $83 \%$ of the participants knew about chlid growth and more than $50 \%$ participant only once a month communicating with health workers.

Keywords: underweight children under three, Integrated services post (posyandu), education 


\section{PENDAHULUAN}

Anak adalah calon generasi penerus bangsa yang perlu disiapkan sejak dini sehingga mampu menjadi Sumber Daya Manusia (SDM) penerus bangsa yang berkualitas (Tessa dkk, 2016). SDM yang berkualitas adalah SDM yang memiliki fisik yang tangguh, mental yang kuat, kesehatan yang prima, dan mempunyai otak yang cerdas (Badan Pusat Statistik Indonesia, 2017). Proses untuk menyiapkan SDM yang berkualitas seharusnya sudah dimulai sejak perencanaan pernikahan, masa (kehamilan, kelahiran, anak, dewasa, hingga lansia). Asupan gizi seimbang dan memadai pada setiap tahapan usia tersebut, sangat berpengaruh terhadap kualitas SDM nantinya (Loeziana, 2015). Masa yang paling kritis adalah masa kehamilan dan kelahiran sampai dengan usia 1000 hari pertama kelahiran (Suryono, 2017). Masa tersebut dikatakan sebagai masa kritis karena merupakan masa emas tumbuh kembang anak yang akan menentukan kualitas generasi bangsa di masa yang akan datang. Pada seribu hari pertama kelahiran (bayi baru lahir sampai dengan batita), normalnya bayi akan mengalami fase tumbuh kembang yang sangat pesat, termasuk fase pematangan kemampuan otaknya. Pada masa ini perkembangan tinggi badan anak mencapai setengah dari tinggi badan orang dewasa; perkembangan volume otak mencapai $90 \%$ volume otak dewasa; perkembangan otak mencapai $80 \%$ otak dewasa; kognitif, mental, dan emosional anak berkembang pesat. (Suryono,2017; Loeziana, 2015;R. Panji, 2014;Aris, 2014). Oleh karena itu, pada usia tersebut diperlukan zat gizi yang bermutu dan memadai. Saat janin, zat gizi diperoleh melalui placenta dari ibu ke janinnya. Saat bayi, umumnya zat gizi dapat dicukupi oleh Air Susu Ibu (ASI), terutama jika ibu dapat memberikan ASI eksklusif minimal selama 6 bulan. Setelah usia 6 bulan, zat gizi yang diterima oleh bayi lebih beragam, karena bayi telah mampu menerima Makanan Pendamping ASI (MP-ASI). Apabila pada 1000 hari pertama kelahiran, bayi tidak mendapatkan asupan gizi yang seimbang dan memadai, maka anak akan berada pada status gizi kurang/buruk. Status gizi adalah keadaan tubuh yang merupakan hasil akhir dari keseimbangan antara zat gizi yang masuk ke dalam tubuh dan utilisasinya. Berdasarkan Direktorat Gizi Masyarakat tahun 2018 anak mendapat status gizi kurang apabila berat badan di bawah atau kurang dari -2 SD. Sebaliknya, anak mendapat status gizi buruk apabila berat badan di bawah atau kurang dari -3 SD. Dampak dari status gizi kurang/buruk adalah terjadinya hambatan pada tumbuh kembang anak, seperti kecerdasan menurun, anak sulit berkonsentrasi, anak lebih pendek dan kurus dari teman-teman 
seusianya, serta anak mudah terkena penyakit.

Pemerintah bertanggung jawab untuk menyediakan sarana dan prasarana kesehatan sehingga masyarakat dapat memperoleh layanan kesehatan yang layak secara merata (Badan Pusat Statistik Indonesia, 2017). Salah satu upaya yang telah dilakukan pemerintah adalah meningkatkan layanan kesehatan melalui puskesmas. Keberadaan puskesmas diharapkan dapat meningkatkan pemerataan layanan kesehatan serta menurunkan angka kesenjangan baik kesenjangan antar wilayah maupun angka kesenjangan antara kaya dan miskin (Pusat Statistik Indonesia, 2017). Saat ini, keberadaan puskesmas sudah ada hampir di setiap kecamatan.

Kecamatan Sawahan terletak di wilayah Surabaya selatan, Kota Surabaya. Topografi kecamatan Sawahan berbentuk dataran rendah dan secara geografis terletak pada ketinggian $4 \mathrm{~m}$ dari permukaan laut; di arah utara berbatasan dengan kecamatan Bubutan; di sebelah timur berbatasan dengan kecamatan Tegalsari, kecamatan Genteng dan kecamatan Wonokromo; di sebelah selatan berbatasan dengan kecamatan Wonokromo, dan kecamatan Dukuh Pakis; serta di sebelah barat berbatasan dengan kecamatan Dukuh Pakis dan kecamatan Sukomanunggal (Badan Pusat Statistik Kota Surabaya, 2017). Kecamatan
Sawahan terdiri dari 6 kelurahan, yaitu kelurahan Pakis, Putat Jaya, Banyu Urip, Kupang Krajan, Petemon, dan Sawahan (Badan Pusat Statistik Kota Surabaya, 2018). Jumlah penduduk kecamatan Sawahan pada tahun 2016 sebanyak 230.001 yang terdiri dari 64.708 keluarga, dengan rata-rata 3,55 jiwa/keluarga (Badan Pusat Statistik Kota Surabaya, 2017). Indikator Kesejahteraan Rakyat (IKR) Kota Surabaya pada tahun 2017 menunjukkan bahwa kecamatan Sawahan merupakan salah satu kecamatan dengan penduduk terpadat kedua di Kota Surabaya (Badan Pusat Statistik Kota Surabaya, 2017). Kecamatan Sawahan ini mempunyai tingkat kepadatan penduduk sebesar 25.454 jiwa $/ \mathrm{km}^{2}$ yang tersebar pada daerah seluas $6,93 \mathrm{~km}^{2}$ (Badan Pusat Statistik Kota Surabaya, 2018). Tingkat kepadatan penduduk kecamatan Sawahan ini jauh melebihi tingkat kepadatan penduduk di Kota Surabaya yang sebesar 8.796 jiwa $/ \mathrm{km}^{2}$ (Badan Pusat Statistik Kota Surabaya,2018). Pelayanan kesehatan di kecamatan Sawahan dibantu oleh 3 puskesmas, salah satu diantaranya adalah puskesmas Sawahan. Pelayanan yang diberikan oleh puskesmas Sawahan terutama diperuntukkan bagi masyarakat di kelurahan Sawahan dan Petemon. Berdasarkan data direktorat gizi masyarakat tahun 2018 menunjukkan bahwa jumlah balita gizi kurang di 
kelurahan Sawahan dan Petemon masih cukup banyak, lihat Tabel 1.

Apabila balita gizi kurang yang ada di kelurahan Sawahan dan Petemon tidak segera ditangani dengan baik, maka balita tersebut berpotensi berubah status menjadi gizi buruk. Kondisi tersebut dapat memperburuk kualitas SDM generasi penerus bangsa. Pemberian Makanan Tambahan (PMT) merupakan salah satu strategi suplementasi yang dapat dilakukan dalam rangka mencukupi kekurangan kebutuhan gizi. Namun dalam pelaksanaannya, hal ini sulit dilakukan. karena kebanyakan ibu balita merupakan ibu yang bekerja serta mempunyai keterbatasan pengetahuan tentang kesehatan, sehingga PMT yang seharusnya diberikan dalam jangka waktu panjang selama masa pertumbuhan balita, berpotensi tidak dilaksanakan oleh ibu tersebut. Oleh karena itu perlu dilakukan edukasi secara terus menerus sehingga dapat meningkatkan kesadaran dan kemandirian ibu tersebut.

Tabel 1. Jumlah Balita Gizi Kurang di Kelurahan Sawahan dan Petemon 2018 (Direktorat gizi masyarakat,2018)

\begin{tabular}{|c|c|c|c|c|}
\hline \multirow{2}{*}{ Bulan } & \multicolumn{2}{|c|}{$\begin{array}{c}\text { Jumlah } \\
\text { balita gizi } \\
\text { kurang di } \\
\text { Kelurahan } \\
\text { Sawahan }\end{array}$} & \multicolumn{2}{|c|}{$\begin{array}{c}\text { Jumlah } \\
\text { balita gizi } \\
\text { kurang di } \\
\text { Kelurahan } \\
\text { Petemon }\end{array}$} \\
\cline { 2 - 5 } & L & P & L & P \\
\hline Januari 2018 & 7 & 9 & 7 & 8 \\
\hline Februari 2018 & 7 & 8 & 7 & 9 \\
\hline Maret 2018 & 7 & 7 & 7 & 8 \\
\hline April 2018 & 7 & 7 & 7 & 8 \\
\hline Mei 2018 & 9 & 7 & 8 & 9 \\
\hline Juni 2018 & 9 & 7 & 8 & 9 \\
\hline Juli 2018 & 9 & 7 & 8 & 8 \\
\hline Agustus 2018 & 8 & 7 & 7 & 7 \\
\hline
\end{tabular}

Upaya yang selama ini telah dilakukan oleh puskesmas Sawahan untuk menangani status gizi balita di wilayah kelurahan Sawahan dan Petemon adalah dengan melakukan penyuluhan berkala, mengontrol kondisi gizi balita melalui penimbangan berat badan dan mengukur tinggi badan, serta pembagian makanan tambahan. Upaya tersebut dilaksanakan melalui posyandu yang dikelola oleh puskesmas, sehingga posyandu menjadi ujung tombak pelayanan kesehatan karena bersentuhan langsung dengan masyarakat. Pertemuan posyandu biasanya dilakukan 2 bulan sekali, kegiatan yang dilakukan untuk penimbangan berat badan dan pengukuran tinggi badan serta untuk penyuluhan dan pembagian makanan tambahan. Selama ini penyuluhan diberikan secara lisan atau menggunakan leaflet. Ada beberapa kader kesehatan yang memanfaatkan lembar balik yang dibeli sendiri untuk memberikan materi penyuluhan. Penyampaian materi penyuluhan secara lisan atau menggunakan leaflet seringkali tidak menarik perhatian balita sehingga balita cenderung untuk melakukan aktifitas lain guna menarik perhatian ibu yang saat itu tertuju pada materi penyuluhan. Hal ini mengakibatkan perhatian ibu beralih pada anak sehingga materi penyuluhan tidak tersampaikan dengan baik. Kondisi penyuluhan dan waktu pertemuan yang terbatas dinilai kurang 
dapat meningkatkan kesadaran dan kemandirian para ibu.

\section{GAMBARAN UMUM MASYARAKAT SASARAN}

Potensi permasalahan mitra di wilayah kerja puskesmas Sawahan adalah gizi kurang pasca kejadian balita gizi buruk dapat berpotensi menjadi kondisi stunting (anak bertubuh pendek). Kondisi tersebut dapat menurunkan kualitas SDM generasi penerus bangsa. Detail dari permasalahan yang ada pada mitra adalah:

1.Keterbatasan pengetahuan yang dimiliki oleh tenaga kesehatan dan ibu balita gizi kurang, perkembangan ilmu di dunia kesehatan mengharuskan tenaga kesehatan untuk memperbarui ilmu yang dimilikinya. Selain itu, perlu adanya transfer ilmu ke ibu posyandu terkait pentingnya makanan tambahan untuk mencegah terjadinya kondisi gizi kurang karena kebanyakan ibu peserta posyandu tidak memiliki latar pendidikan di bidang kesehatan.

2.Keterbatasan jumlah tenaga kesehatan untuk melayani salah satu kecamatan dengan penduduk terpadat di Surabaya.

3.Keterbatasan waktu dan media berkumpul untuk saling tukar menukar pengalaman atau informasi antara ibu batita gizi kurang, penyampaian informasi dari tenaga kesehatan ke ibu peserta posyandu, dan pengontrol pertumbuhan gizi dari batita, tukar pengalaman dan informasi sangat diperlukan untuk memperkaya pengetahuan dan kemampuan khususnya ibu peserta posyandu.

4.Keterlambatan atau bahkan lupa akan waktu dan jenis makanan tambahan yang perlu diberikan kepada batita. Kondisi ini dapat mengakibatkan batita menjadi kurang gizi bahkan dapat mempunyai tubuh pendek. Untuk itu perlu adanya kontrol dan pengingat waktu secara rutin agar ibu tidak terlambat atau lupa untuk memberikan makanan tambahan.

Ibu peserta posyandu biasanya kurang bisa berkonsentrasi mengikuti materi penyuluhan yang diberikan tenaga kesehatan. Dikarenakan Ibu peserta posyandu membawa anaknya saat datang di penyuluhan. Anak pada usia batita biasanya tidak bisa duduk diam sehingga si ibu sibuk untuk mengawasi anaknya dan kurang dapat berkonsentrasi dengan materi yang diberikan oleh tenaga kesehatan.

\section{METODE}

Tahapan kegiatan edukasi pemberian makanan tambahan bagi ibu batita gizi kurang adalah sebagai berikut:

1. Studi pendahuluan dilakukan untuk mengidentifikasi karakteristik (sosial, ekonomi, kesehatan, dan status gizi), pola makanan, dan status gizi batita gizi kurang di kelurahan Sawahan 2018. 
2. Pengembangan rencana kegiatan untuk pelaksanaan kegiatan penyuluhan, demo masak, dan penimbangan badan batita gizi kurang di kelurahan Sawahan.

3. Identifikasi, formulasi dan pengembangan makanan keluarga untuk intervensi berdasarkan usia, ketersediaan lokal dan kandungan gizi yang dibutuhkan untuk memperbaiki status gizi batita di kelurahan Sawahan Kota Surabaya.

4. Identifikasi jenis makanan dan kerjasama dengan mahasiswa Informatika untuk pemaparan penyediaan pangan yang digunakan dalam intervensi (PMT).

5. Sosialisasi program PMT yang ada di internal Puskesmas Sawahan kepada Ibu Batita gizi kurang dengan tim pengabdian masyarakat Ubaya.

6. Pemilihan peserta kegiatan edukasi pemberian makanan tambahan untuk batita gizi kurang di kelurahan Sawahan tahun 2018.

7. Penyediaan dan demo masak makanan keluarga dalam lingkup pemberian makanan tambahan untuk intervensi.

8. Monitoring, evaluasi dan kepatuhan konsumsi pemberian makanan tambahan dalam sesi tanya jawab pada kegiatan penyuluhan.

9. Pendidikan gizi untuk peserta dan bukan peserta PMT.
10. Pengumpulan data berupa kuisioner dan status gizi dari KMS, keluhan dan manfaat pemberian makanan tambahan, pengetahuan gizi serta prestasi akademik.

11. Analisis data untuk mengetahui pengaruh kegiatan pemberian makanan tambahan.

12. Pengembangan keberlanjutan program PMT dari pemerintah untuk batita.

\section{HASIL DAN PEMBAHASAN}

Untuk mengetahui kondisi awal, tim menyebarkan kuisioner di 2 posyandu kecamatan Sawahan, Surabaya. Hasil kuisioner menunjukkan bahwa $83 \%$ ibu-ibu peserta posyandu mengetahui perkembangan tumbuh kembang anak mereka saat penimbangan berat badan di posyandu yang biasanya dilakukan 1 bulan sekali. Selain itu, lebih dari 50\% ibu-ibu peserta posyandu yg hanya mengkomunikasikan perkembangan tumbuh kembang anak mereka 1 bulan sekali dengan tenaga kesehatan dari posyandu. Keadaan di atas menjadi tantangan bagi para tenaga kesehatan untuk berusaha lebih keras mengedukasi ibu-ibu peserta posyandu akan pentingnya kesehatan anak. Untuk membantu tenaga kesehatan di Puskesmas Sawahan, Surabaya, tim PPM menawarkan 3 macam program, yaitu: kolaborasi kemitraan dan peningkatan kemandirian masyarakat rentan gizi. 


\section{A. Kolaborasi Mitra}

Kolaborasi Kemitraan antara tenaga kesehatan Posyandu dengan dosen Ilmu Kesehatan Masyarakat dan Teknik Informatika Universitas Surabaya untuk transfer pengetahuan ke tenaga kesehatan, mengedukasi kedua mitra akan pentingnya pemanfaatan teknologi, dan mengedukasi ibu yang memiliki batita gizi kurang sebagai pelaksana langsung melalui program penyuluhan atau Focus Group Discussion (FGD), dan demo cara membuat makanan tambahan alternatif.

Perkembangan ilmu kesehatan harus diikuti oleh tenaga kesehatan yang berperan sebagai promotor kesehatan lingkungan dan masyarakat sebagai pelaksana langsung. Adanya peningkatan pengetahun diharapkan akan membantu meningkatkan pola hidup sehat masyarakat. Peningkatan pengetahuan dapat diperoleh melalui transfer pengetahuan dari tenaga ahli ataupun informasi yang didapatkan dari internet. Transfer pengetahuan dari tenaga ahli akan dilakukan melalui program penyuluhan atau Focus Group Discussion (FGD).

Beberapa kegiatan sosialisasi melalui metode penyuluhan dilakukan oleh tim, seperti pada Gambar 1. Setelah sesi penyuluhan, tim menyediakan waktu untuk sesi tanya jawab, seperti pada Gambar 2.
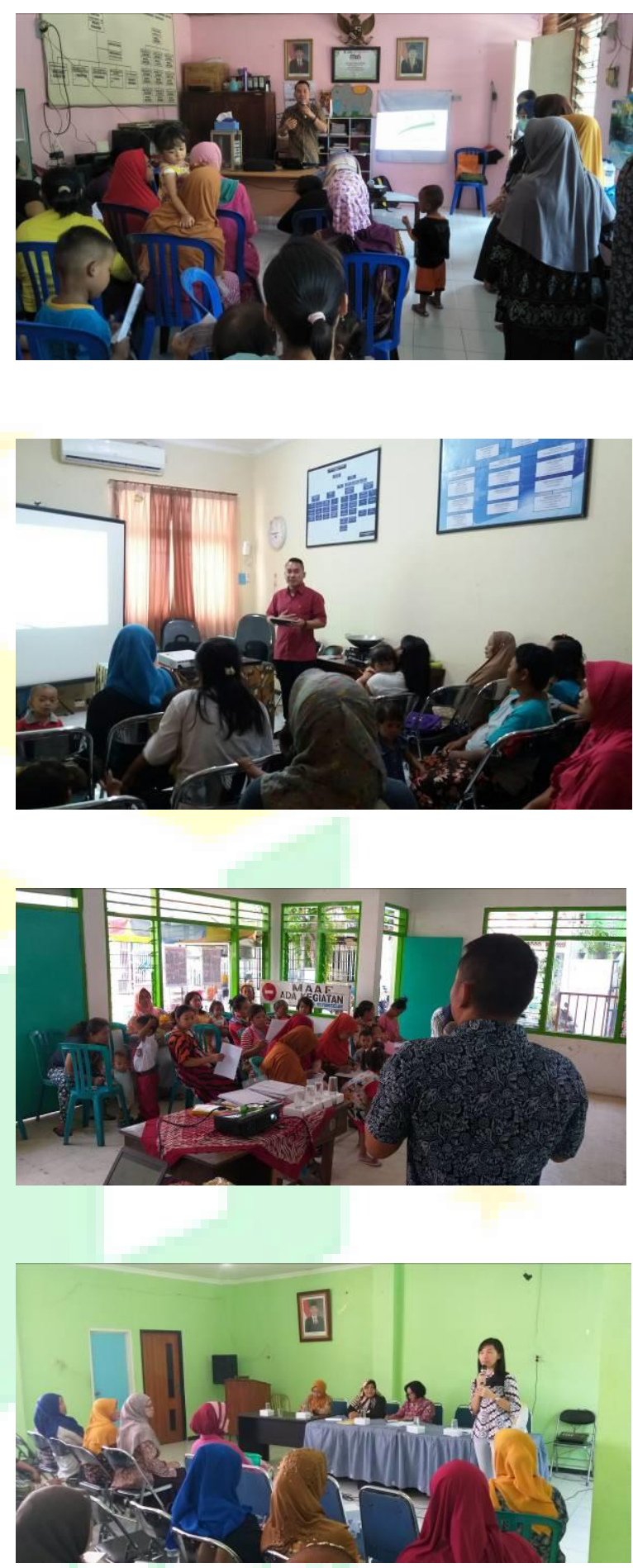

Gambar 1. Penyuluhan oleh Tim pengabdian masyarakat Ubaya 

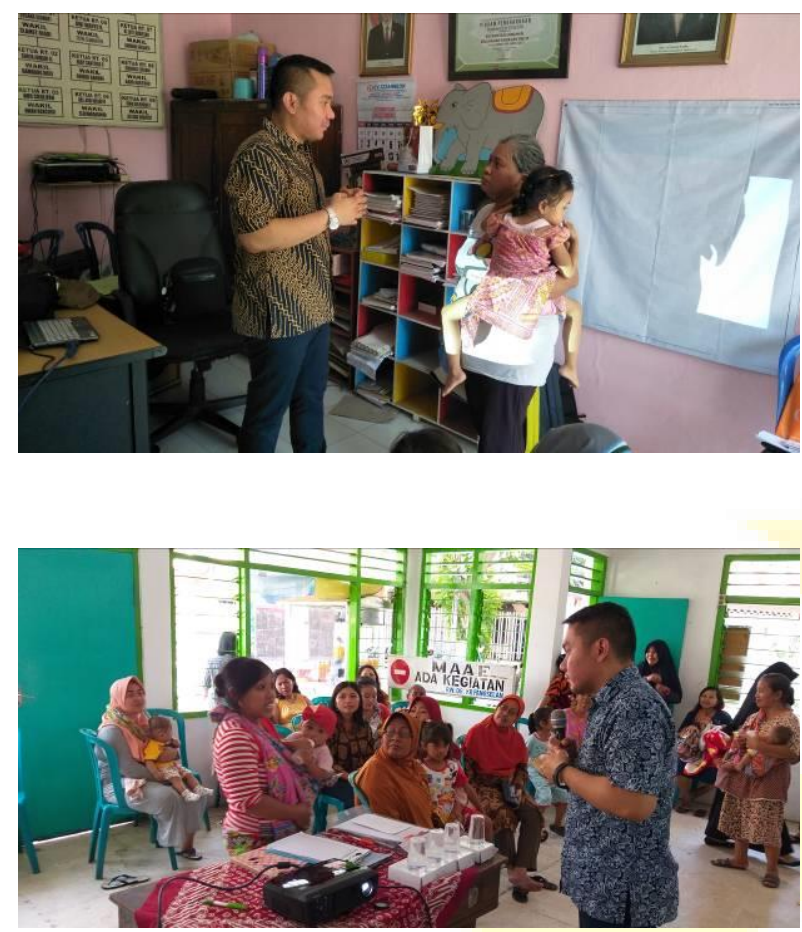

Gambar 2. Sesi Tanya Jawab antara tim pengabdian masyarakat Ubaya dengan ibuibu peserta posyandu

Salah satu cara untuk meningkatkan minat para ibu dalam Edukasi tentang Pemberian Makanan Tambahan (PMT) adalah dengan memberikan ketrampilan dalam berkreasi membuat makanan tambahan alternatif. Hal ini dapat dilakukan melalui demo membuat makanan tambahan alternatif bagi batita, seperti pada Gambar 3 .

\section{B. Peningkatan Kemandirian Masyarakat}

\section{Rentan Gizi}

Peningkatan kemandirian masyarakat rentan gizi, dengan cara meningkatkan kesadaran dan pengetahuan ibu batita gizi kurang, yang difokuskan pada edukasi mengenai Pemberian Makanan Tambahan (PMT).
Kemandirian masyarakat rentan gizi diawali dengan meningkatkan pengetahuan ibu tentang PMT untuk menumbuhkan kesadaran pentingnya PMT bagi tumbuh kembang anak. Apabila ibu telah menyadarinya, selanjutnya kondisi ibu akan meningkat menjadi kesiapan untuk berubah (readiness to change). Kondisi ini akan mempermudah untuk menerapkan materi edukasi dan melakukan perubahan. Ibu batita gizi kurang yang menjadi agent of change, dapat menjadi panutan nyata yang positif bagi masyarakat lainnya.
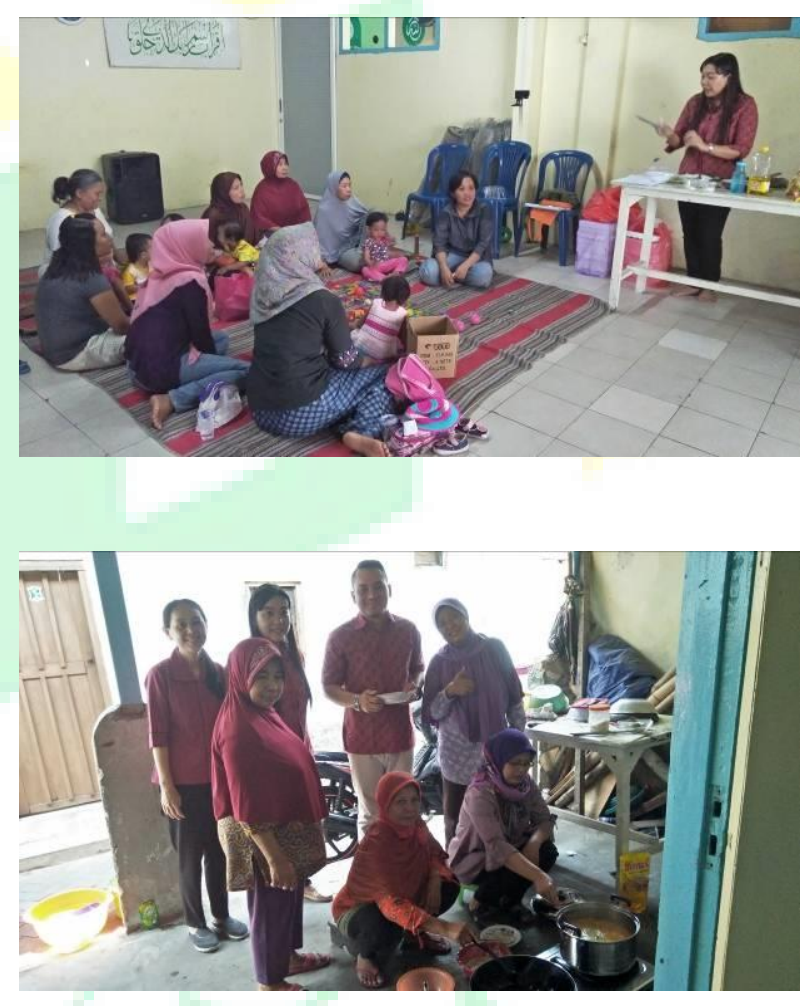

Gambar 3. Demo memasak pembuatan makanan tambahan alternatif bagi batita

Keterbatasan memori untuk mengingat waktu dan jenis PMT yang harus diberikan kepada anak dapat dibantu dengan adanya 
kalendar. Pada kalendar yang dibuat, tanggal-tanggal tertentu akan diisi jenis PMT yang harus diberikan kepada anak dan resep variasi makanan tambahan alternatif. Adanya kalendar ini diharapkan membantu para ibu untuk mengingat waktu dan jenis PMT tanpa perlu menunggu instruksi dari tenaga kesehatan.

Kurangnya konsentrasi ibu saat mendengarkan materi penyuluhan PMT akan dibantu dengan adanya leaflet (Gambar 4). Leaflet akan memberikan informasi mengenai perlunya PMT dan jenis makanan tambahan yang boleh diberikan kepada anak sesuai dengan usianya. Selain itu, untuk membantu para ibu berkreasi dalam membuat makanan, akan diberikan buku resep kreasi makanan tambahan selama 30 hari (Gambar 5). Buku resep ini diharapkan akan menambah pengetahuan ibu untuk berkreasi membuat PMT secara mandiri.

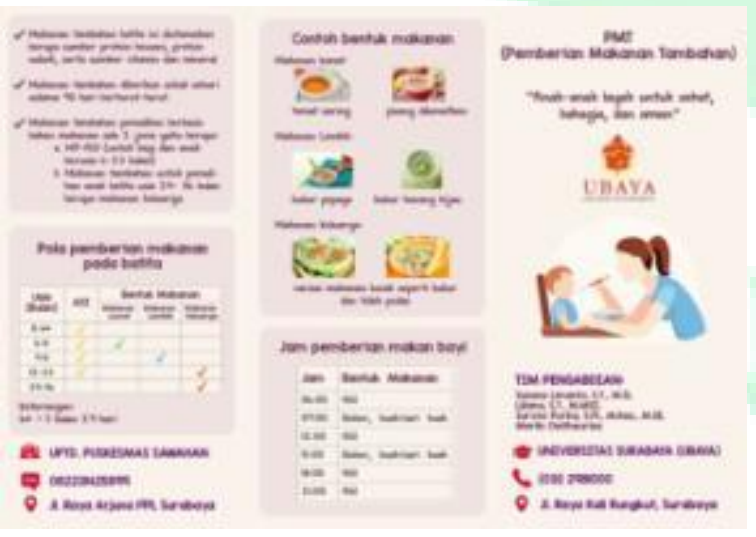

Gambar 4. Contoh Leafet
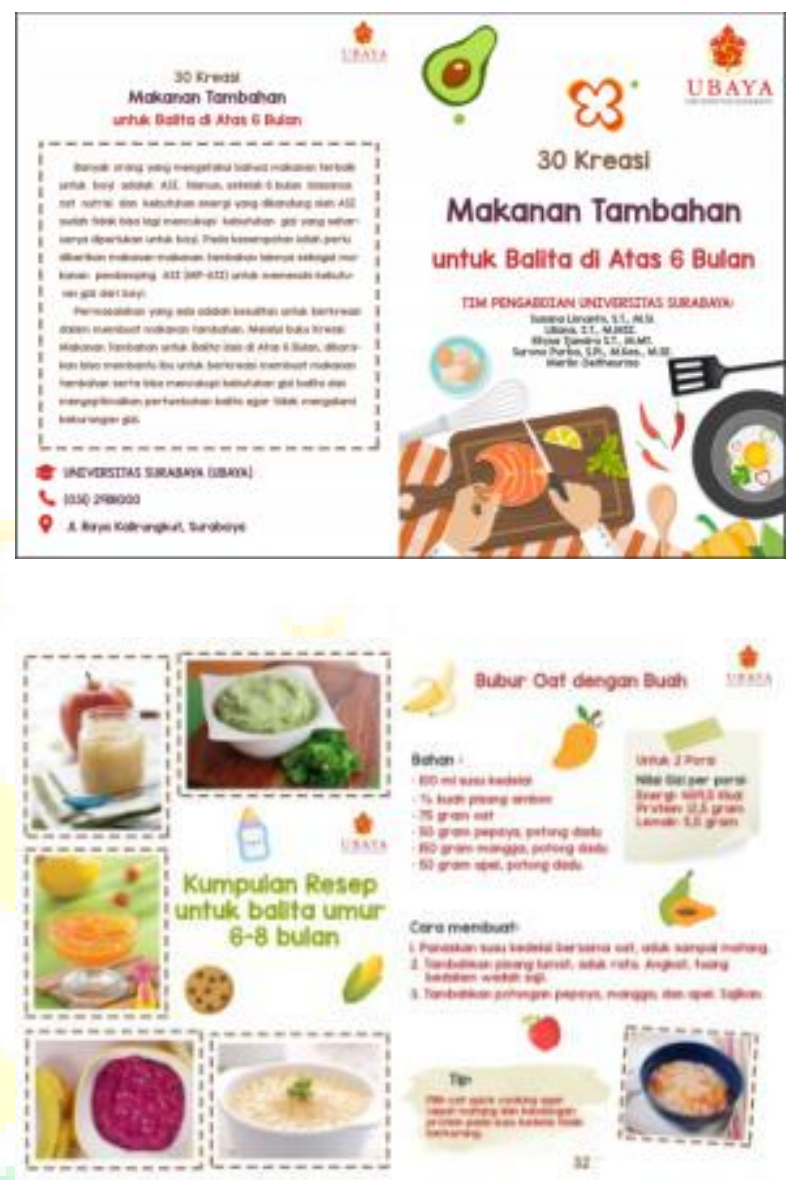

Gambar 5. Contoh buku resep mengenai Pemberian Makanan Tambahan (PMT)

\section{KESIMPULAN}

Tujuan program pemberian makanan tambahan adalah menambah asupan zat gizi melalui makanan tambahan. Selama 3 (tiga) bulan selama kegiatan menerima paket makanan yang diberikan pada peserta untuk batita yang diharapkan sebagai konsumsi yang tidak akan menggantikan waktu makan. Untuk memastikan tujuan kegiatan program pemberian makanan tambahan terlaksana dengan baik, peserta diminta untuk mengisi lembar untuk menandatangani sebagai lembar pengambilan konsumsi yang berupa makanan olahan pabrik. 
Sebagai salah satu indikator utama keberhasilan program adalah peningkatan konsumsi pangan. Pengukuran konsumsi pangan dilakukan dengan tanya jawab untuk diidentifikasi berbagai jenis dan ukuran makanan yang telah dikonsumi oleh batita dari peserta. Secara umum diperoleh hasil kenaikan jumlah asupan zat gizi baik peserta yang telah memberikan ASI sebelum diberikan pemberian makanan tambahan. Hal ini menunjukkan bahwa pemberian makanan tambahan menambahkan zat gizi, dan tidak menggantikan kebiasaan mereka, akan tetapi masih terdapatnya sebagian peserta yang mengalami defisit zat gizi tersebut karena rendahnya alokasi uang saku untuk belanja makanan, dan sebagian peserta susah memonitoring pola makanan batita karena kesibukan bekerja.

Pengetahuan gizi peserta merupakan salah satu indikator yang dipilih sebagai indikator keberhasilan program PMT. Program PMT tidak hanya memberikan makanan tambahan semata tapi juga memperbaiki pengetahuan gizi, zat gizi dan pengetahuan tentang kesehatan. Pengetahuan gizi diberikan tidak hanya peserta yang selalu memberikan ASI kepada batita tetapi juga diberikan kepada semua peserta yang memberikan susu formula kepada batita. Untuk mengevaluasi peningkatan pengetahuan gizi dilakukan dengan melaksanakan pre tes pendidikan gizi atau pemahaman tentang PMT.
Hasil yang diperoleh menunjukkan nilai pengetahuan gizi sebelum (pre-test) diberikan pendidikan gizi secara nyata untuk peserta. Nilai pengetahuan gizi peserta cukup rendah, hal ini menunjukkan bahwa pengetahuan gizi peserta sebagai ibu batita gizi kurang mengenai zat gizi, PMT, dan kesehatan masih kurang. Walaupun sebagian besar peserta tidak dapat menjawab dengan benar untuk beberapa pertanyaan mengenai zat gizi, PMT, dan kesehatan. Sehingga untuk program selanjutnya, metode yang direkomendasikan untuk digunakan adalah metode diskusi kelompok yang lebih insentif dengan masalah gizi sehari-hari.

Dengan meningkatnya informasi dan pendidikan, kesadaran untuk memperbaiki nutrisi dan status gizi juga meningkat. Hal ini dapat memperbaiki kualitas batita kelurahan Sawahan di masa yang akan datang. Tetapi memang tidak mudah dan tidak instan, karena untuk dapat memperbaiki rata anak di suatu bangsa membutuhkan waktu yang sangat lama. Sebagai contoh bangsa Belanda memerlukan waktu 150 tahun untuk menghasilkan generasi yang tingginya 20 $\mathrm{cm}$ lebih tinggi dari tinggi rata generasi sebelumnya. Bangsa Korea memerlukan waktu 100 tahun untuk menghasilkan generasi yang tingginya $20 \mathrm{~cm}$ lebih tinggi dari tinggi rata generasi sebelumnya. Begitu juga bangsa lainnya, semoga ke depannya 
bangsa Indonesia juga mengikuti tren meningkatnya rata tinggi badan generasi mendatang. Karena faktanya sudah banyak anak Indonesia yang memiliki tinggi badan baik seiring dengan perbaikan pola makan menjadi lebih baik.

\section{REFERENSI}

Aris Priyanto. 2014. Pengembangan Kreativitas pada Anak Usia Dini melalui Aktivitas Bermain. Jurnal Ilmiah Guru "COPE”.Nomor 02/Tahun XVIII, Hal: 41-47.

Badan Pusat Statistik Indonesia. 2017. Indikator Kesejahteraan Rakyat, Diunduh dari :

https://www.bps.go.id/publication/dow nload.html?nrbvfeve=ZGM5ODljOGR hY2U0NWViNDFmZDliYmM1\&xzm n=aHR0cHM6Ly93d3cuYnBzLmdvL mlkL3B1YmxpY2F0aW9uLzIwMTcv MTEvMjgvZGM5ODljOGRhY2U0N WViNDFmZDliYmM1L2luZGlrYXR vci1rZXNlamFodGVyYWFuLXJha3lh dC0taW5rZXNyYS0tMjAxNy5odG1s \&twoadfnoarfeauf=MjAxOS0wMS0x OCAxNToyNDozOA\%3D\%3D. Diunduh tanggal: 18 Januari 2019.

Badan Pusat Statistik Kota Surabaya. 2017. Indikator Kesejahteraan Rakyat Kota Surabaya, Diunduh dari : https://surabayakota.bps.go.id/publicati on/download.html?nrbvfeve $=\mathrm{MzQ} 3 \mathrm{Mz}$ ZjNjkxMTA5YTQ2YjljN2JiN2Q2\&xz $\underline{m n=a H R 0 c H M 6 L y 9 z d X J h Y m F 5 Y W t v}$ dGEuYnBzLmdvLmlkL3B1YmxpY2F 0aW9uLzIwMTcvMDEvMDMvMzQ3 MzZjNjkxMTA5YTQ2YjljN2JiN2Q2 L2luZGlrYXRvci1rZXNlamFodGVyY WFuLXJha3lhdC1rb3RhLXN1cmFiY XlhLTIwMTcuaHRtbA\%3D\%3D\&tw oadfnoarfeauf=MjAxOS0wMS0xOCA xNTozNDowMw\%3D\%3D. Diunduh tanggal: 18 Januari 2019.
Badan Pusat Statistik Kota Surabaya. 2017. Kecamatan Sawahan dalam Angka. Diunduh dari: https://surabayakota.bps.go.id/publicati on/download.html?nrbvfeve $=$ YWFmN DEyMWYzNzY5YWRkNzZjYzMwM GQ0\&xzmn=aHR0cHM6Ly9zdXJhY mF5YWtvdGEuYnBzLmdvLmlkL3B1 YmxpY2F0aW9uLzIwMTcvMTIvMjk vYWFmNDEyMWYzNzY5YWRkNz ZjYzMwMGQ0L2tlY2FtYXRhbi1zY XdhaGFuLWRhbGFtLWFuZ2thLTIw MTcuaHRtbA\%3D\%3D\&twoadfnoarf eauf=MjAxOS0wMS0yMyAxMzozM To1NA\%3D\%3D. Diunduh tanggal: 23 Januari 2019.

Badan Pusat Statistik Kota Surabaya. 2018. Luas Wilayah Kota Surabaya Menurut Kelurahan 2016. Diunduh dari: https://surabayakota.bps.go.id/statictabl e/2018/01/30/581/luas-wilayah-kotasurabaya-menurut-kelurahan-2016html. Diunduh tanggal: 21 Januari 2019.

Direktorat Gizi Masyarakat.2018.Buku Saku Pemantauan Status Gizi Tahun 2017. Diunduh dari: http://www.kesmas.kemkes.go.id/assets/ upload/dir_519d41d8cd98f00/files/Buk u-Saku-Nasional-PSG-2017_975.pdf. Diunduh tanggal: 23 Januari 2019.

Loeziana Uce. 2015. The Golden Age: Masa Efektif Merancang Kualitas Anak. Jurnal Pendidikan Anak. Volume 1. Nomor 2. Hal: 77-92.

R.Panji Hermoyo. 2014. Membentuk Komunikasi yang Efektif pada Masa Perkembangan Anak Usia Dini. Jurnal Pedagogi. Volume 1. Nomor 1. Hal: 122.

Suryono Yudha Patria. 2017. Gizi Anak pada Masa Emas (Golden Age). Diunduh dari: http://fk.ugm.ac.id/wpcontent/uploads/2017/09/Gizi-AnakGolden-Age.pdf. Diunduh tanggal: 21 Januari 2019. 
Tessa Siswina, M. Nurhalim Shahib, Adjat S Rasyad.2016. Pengaruh Stimulasi Pendidikan Terhadap Perkembangan
Kecerdasan Anak Usia 3-6 Tahun. Jurnal IImiah Bidan. Volume 1. Nomor 2. Hal: 27-33. 